\title{
O CUSTO DE UMA DEVOÇÃO: \\ Horas de Trabalho e Itens de um Ritual do Candomblé no início do século XX
}

\section{THE COST OF A DEVOTION, HOURS OF WORK AND ITEMS OF A CAMDOMBLE RITUAL OF THE EARLY TWENTIETH CENTURY}

Flávio Gonçalves dos Santos*

\begin{abstract}
Resumo: Neste texto analisa-se a interseção entre a cultura material, isto é, as relações comerciais de objetos de culto aos orixás e as formas de prestação de serviços dos terreiros de candomblés. A partir de fontes bibliográficas e jornalísticas, foi possível apreender as nuanças que reproduziam o mercado consumidor dos objetos de culto aos orixás. Essas fontes foram tão valiosas que ofereceram dados com os quais se vislumbraram os custos para se cultuar os orixás ou para se buscar soluções para os mais variados problemas cotidianos que afligiam as pessoas.
\end{abstract}

Palavras-Chave: História; Brasil-África; Relações ComErciais; Candomblé.

Abstract: This paper analyzes the intersection between material culture and the trade objects of worship to the deities and forms of service yards of Candomblé. From literature sources and journalists, it was possible to grasp the nuances that reproduced the consumer market of the objects of worship to the deities. These sources were so valuable that provided data with which costs are envisioned to worship the deities or to seek solutions for a variety of everyday problems that afflicted people.

Keywords: History; Brazil and Africa; Trade Relations; Candomblé.

(recebido em 29 de fevereiro de 2012; aprovado em 10 de junho de 2012)

É comum associar o exercício da devoção e da fé religiosa ao desprendimento e ao desapego material. Na tradição religiosa judaico-cristã, esse desapego é levado ao máximo nas projeções feitas em relação à conduta dos sacerdotes da Igreja Católica. Essa é uma visão nutrida muito mais pelo "rebanho" do que pelo sacerdócio católico e, menos ainda, fora dos limites do mundo católico e sua noção de piedade.

Assim, quando duas vivências e universos religiosos distintos se encontram, é natural que, no jogo das trocas simbólicas entre eles, valores sejam permutados e, a reboque delas, se cambiem também visões de mundo. Digo isso para enfatizar que a experiência e a manifestação da devoção no candomblé pertencem a outro universo simbólico e religioso, distinto da tradição judaico-cristã. Apesar disso, não se pode negar a profunda influência que ambas excercem entre si, marcadamente em uma sociedade regada por experiências históricas de muita intolerância, sob os auspícios do catolicismo. Desse modo, creio, pode-se compreender, de forma menos * Doutor em História pela Universidade Federal Fluminense (2007) e professor adjunto da Universidade Estadual de
Santa Cruz. 
preconceituosa, a relação custo e benefício para os fiéis e sacerdotes, por ocasião das manifestações de devoção aos orixás.

Antes disso, não só é desejada, como necessária. Por isso não se nota tantos pudores no culto aos orixás, embora eles existam, de se ofertar ou pedir dinheiro. No catolicismo, essa relação é disfarçada pelo sentido de piedade e pela "obrigação" de ser caridoso. Isso faz com que a presença do dinheiro no principal ritual católico, muitas vezes, passe despercebida. Mas 0 fato é que o ofertório, momento em que circula uma cesta ou algo similar entre os fieis, para que depositem suas contribuições destinadas às obras de caridade, à conservação ou à ampliação do templo, dá-se, exatamente, momentos antes do ápice da missa, quando se dá a consagração eucarística, rito antes da comunhão, quando os fiéis recebem a hóstia consagrada.

No candomblé, a presença do dinheiro está relacionada, invariavelmente, a uma prestação de "serviço mágico-religioso". O serviço mágico, analisado anteriormente, trata da consulta aos orixás por meio do jogo de búzios ou consulta ao Ifá. Ele precede a todos os demais pois, é a partir dele que se determina o próximo passo que o devoto deverá adotar para cultuar seu orixá ou livrar-se dos males que o afligem. Esse passo poderá ser um despacho, um ebó ou uma oferenda, como também uma combinação desses três tipos de procedimentos rituais.

De acordo com José Renato C. Batista, despacho e ebó podem ser definidos, respectivamente, como: "[...] que designa de modo genérico quaisquer oferendas aos deuses. Pode-se
referir, também, a despacho ou feitiço, ou, ainda, aos rituais de cura ou limpeza
espiritual."1

"[...] propiciatória feita a Exu, com a finalidade de enviá-lo como mensageiro aos orixás, solicitando sua boa vontade para a realização de um trabalho religioso ou para evitar sua presença perturbadora [e a oferenda diferencia-se] do ebó e do despacho pelo seu caráter de restituição a uma graça recebida ou de manutenção do vínculo espiritual entre o fiel e suas entidades."2

Em uma consulta aos búzios ou ao Ifá pode ser prescrito ao cliente um despacho, para as quais ele deve adquirir produtos, tais como: milho branco, feijão branco, preto e fradinho, ovos, milho de galinha, alguns metros de morim branco, folhas, velas, acaçás e, eventualmente, um pombo, uma galinha, ou um novelo ou carretel de linha, sendo esses itens variáveis de acordo com o objetivo e a gravidade do caso. Invariavelmente, os despachos são prescritos com a finalidade de curar doenças ou livrar uma pessoa de alguma entidade malfazeja que a

\footnotetext{
1 BATISTA, 2005, p. 70.
}

2 Ibidem, p. 70. 
atormenta e/ou atrapalha sua vida. Para livrar o corpo e o espírito da pessoa, do mal que a aflige, os itens prescritos podem ser passados no seu corpo, ao tempo que se proferem orações e pedidos aos orixás para que seja purificada.

Em 1919, por exemplo, o jornal O Tempo noticiou o diagnóstico e a prescrição de um despacho feito a Pedro de Almeida Santos, um repórter que se consultara com o pai de santo Jubiabá, tendo como objetivo escrever a matéria para o jornal.3 Segundo o jornal, o diagnóstico foi o seguinte:

\begin{abstract}
"Vejo o Sr. cercado de muitas attribulações em sua vida. Acerca de dous annos os seus negocios em matéria de dinheiro não andam bem. Dous espiritos vivem a perseguil-o, parecendo um deles ser 0 do seu proprio pae, mas ao lado delles existe um outro espirito bom que não consente a sua approximação. Vejo também moléstia grave e pessoa de sua família que esteve prestes a desencarnar-se. Existe uma mulher que pretende promover a descordia em sua vida, assim como vejo tambem planos de uma viagem por motivo de moléstia. Os seus negócios não andam bons."4
\end{abstract}

Quanto à prescrição do remédio para os males que afligiam Pedro Santos, Jubiabá disse:

\footnotetext{
"- Tenha fé e confiança que o senhor se dá muito bem. Traga-me com urgência sete velas, sete vinténs de cobre, um litro de milho e 25.000 rs. Em dinheiro. Se porventura não tiver o dinheiro todo, traga em prestações que eu aceito." 5
}

É possível, a partir dos valores apurados por M. J. Herskovits, ter uma ideia aproximada do custo desse despacho6, pontuando serem eles pertinentes ao ano de 1937. Ao que tudo indica, os preços devem ter-se mantido estáveis, já que o valor apurado por esse autor, para uma consulta aos búzios, foi o mesmo cobrado por Jubiabá, como observado pela matéria do jornal O Tempo:

"O celebre Severiano de Abreu, assumindo aspecto mais grave, fitou-nos sentando-se depois.

- Cinco mil réis, disse-nos ele.

Pagamos a quantia."7

A respeito da adivinhação, Herskovits assim comentou:

\footnotetext{
3 O TEMPO,1919.

4 Idem.

5 Ibidem.

6 HERSKOVITS, 1958.

7 O TEMPO, 1919.
} 
"Fees from divination are not negligible; cult-centers are reported where thirty to forty clients are several daily, at a cost fairly well standardized in the city, of $5 \$ 000$ per consultation."8

É preciso notar que $5 \$ 000$ foi a mesma quantia cobrada por Martiniano E. do Bonfim e por mãe Sabina a seus respectivos consulentes, em 1938, nos casos relatados por Landes e anteriormente analisados. Se não há discrepância em relação ao valor cobrado para consultar os orixás, não seria de todo incorreto supor que os valores médios dos serviços, dos objetos e víveres empregados nos rituais do culto aos orixás permaneceram estáveis entre 1919 e 1937. Partindo desse pressuposto, os valores coletados por Herskovits podem dar uma ideia aproximada do valor do despacho prescrito por Jubiabá ao repórter de 0 Tempo.

Ao somar os $25 \$ 000$, cobrados pela execução do serviço mágico-religioso, aos $5 \$ 000$ cobrados para realizar a consulta aos orixás, tem-se $30 \$ 000$ de custo. Considerando que um litro equivale a, mais ou menos, $1 \mathrm{~kg}$ de milho, e que Herskovits apurou que três quilos de milho amarelo custavam $1 \$ 200$, um litro dele deveria custar, aproximadamente, $\$ 400.9$ Tomando esses valores como referência, acrescentando o preço do litro de milho e os $\$ 140$, referentes aos sete vinténs, o valor total do despacho foi, nada menos, que 30\$540. É provável que essa soma tenha se elevado um pouco, já que o preço de sete velas, que faziam parte do despacho, não foi agregado.

Essa quantia equivale, em 1920 a, aproximadamente, 13 dias de trabalho de um profissional de edificações, cujos vencimentos diários médios eram de $2 \$ 294,10$ ou a 20 dias de trabalho de uma operária do mesmo ramo de ocupação, cuja média salarial diária era de $1 \$ 500$, ambos maiores de 14 anos.

Diante desse quadro de salários muito achatados, entende-se porque Jubiabá e outros pais e mães de santo se dispunham a aceitar o dinheiro cobrado pelos despachos em prestações.

Se $30 \$ 540$ era o custo aproximado de um despacho cuja finalidade era curar e afastar os maus espíritos, os de um ebó não eram menores. Por se tratar de uma oferenda que contém um pedido a Exu e esse orixá é de personalidade zombeteira, temperamental e vingativa, os preços cobrados pelos pais e mães de santo para sua realização eram substanciais.

Há uma identificação muito forte da figura de Exu com a de um espírito malévolo a que as pessoas, mal intencionadas, recorrem com o intuito de aplicar algum tipo de feitiço. Essa identificação encontra sua base no sincretismo religioso que vinculou esse orixá ao diabo. A

\footnotetext{
8 HERSKOVITS, 1958, p. 262.

${ }^{9}$ HERSKOVITS, 1958, p. 257.

${ }^{10}$ BRASIL, [192-] , p. 24-25.
} 
transformação de Exu em diabo, no Brasil, deveu-se principalmente às interpretações próprias da tradição judaico-cristã brasileira. Os mitos que descrevem a ação punitiva e vingativa de Exu deram suporte a esse tipo de associação. É o caso do mito que conta como Exu semeou a discórdia entre dois lavradores por pura vingança, como se vê, a seguir.

\footnotetext{
"Certa vez dois amigos de infância que jamais discutiram, esqueceram-se, numa segunda-feira, de fazer-the as oferendas devidas. Foram para o campo trabalhar, cada um na sua roça. As terras eram vizinhas, separadas apenas por um estreito canteiro. Exu, zangado pela negligência dos dois amigos, decidiu preparar-lhes um golpe, à sua maneira. Ele colocou sobre a cabeça um boné pontudo que era branco do lado direito e vermelho do lado esquerdo. Depois, seguiu pelo canteiro, chegando à altura dos dois trabalhadores amigos e, muito educadamente, cumprimentou-os;

- Bom trabalho, meus amigos!

Estes gentilmente responderam:

- Bom passeio, nobre estrangeiro!

Assim que Exu afastou-se, o homem que trabalhava no campo da direita falou ao companheiro:

- Quem pode ser este personagem de boné branco?

- Seu chapéu era vermelho, respondeu o homem do campo da esquerda.

- Não, ele era branco de um branco de alabastro, o mais belo que existe!

- Ele era vermelho, um vermelho escarlate de fulgor insustentável!

- Ele era branco, tratas de mentiroso?

- Ele era vermelho, ou pensas que sou cego?

Cada um dos amigos tinha razão e estava furioso da desconfiança do outro.

Irritados, eles agarraram-se e começaram a bater-se até matarem-se a golpes de enxada.

Exu estava vingado! Isso não teria acontecido se as oferendas a Exu não tivessem sido negligenciadas. Pois Exu pode ser o mais benevolente dos orixás se é tratado com consideração e generosidade."11
}

O fato é que a ação ardilosa e amoral de Exu fez com que a sua identificação com desígnios malignos eclipsasse a sua verdadeira natureza, isto é, a de mensageiro. É exatamente essa condição que propicia a ele os meios necessários e suficientes para intervir de modo mais eficaz na vida das pessoas. Acontece que a função de Exu, enquanto princípio regulador faz sobressair a sua condição de mensageiro e, como todo mensageiro, é o conhecedor dos caminhos que levam à fortuna ou ao infortúnio. Dessa maneira, quem quer abrir os seus caminhos para a boa sorte ou fechá-la para seus inimigos, deve adular Exu, oferecendo-lhe as comidas que mais o aprazem. Tanto maior é o pedido, maior deve ser 0 animal sacrificado.

Os ebós, muitas vezes denominados também de despachos, via de regra, são feitos para prejudicar um suposto inimigo. Além do sacrifício, consta, sempre, o nome completo da pessoa ou algo pessoal daquele a quem se pretende atingir, tais como: peças de roupa, partes do corpo - cabelos, unhas etc. - e uma boneca ou boneco, espetado com alfinetes ou objetos pontiagudos, representando o alvo do feitiço. Esses itens podem apresentar-se em conjunto, ou

\footnotetext{
11 VERGER, 1981, p. 13.
} 
separadamente, em um ebó, e isso dependerá sempre do tipo de resultado que se espera obter junto a Exu.

Esse tipo de despacho, embora seja o mais associado ao culto das religiões afrobrasileiras e desperte temor e preconceito para com os adeptos dos orixás, é feito com restrições. Acredita-se que parte do "carrego" fica com o pai ou a mãe de santo que o prescreveu e/ou o executou, enfraquecendo o seu próprio axé. 0 carrego é o resíduo de uma força negativa manipulada com o objetivo de prejudicar alguém. Essa força pode estar associada a um Egun, 0 espírito de uma pessoa morta que não foi conduzido ao llú Aiyê, ou seja, mundo dos mortos, por Exu, ou ao próprio lku, isto é, a morte. O Egun, quando é atraído e passa a acompanhar uma pessoa, mesmo involuntariamente, atrai infortúnios, como a doença, a perda de dinheiro, a desarmonia conjugal etc.

Esse é o objetivo dos folclóricos despachos futebolísticos, ainda largamente utilizados. Dessa prática, tão convencional nos dias atuais, tem-se notícias já em 1937:

\begin{abstract}
"Aboletou-se há pouco tempo em uma roça da Estrada da Cruz do Cosme n. 256, um macumbeiro conhecido por Manoelzinho, cujos 'despachos' vêm dando lugar a repetidas reclamações dos moradores e transeuntes daquela estrada [...]

Ao que nos informam, o referido Manoelzinho, pai de santo prestigioso e afamado, é especialista em 'despachos' esportivos, pois entre os que lá estão, alguns são 'alvi-rubro', 'rubro-negros' e 'tricolores'. Um guarda civil nos últimos dias, véspera de um grande jogo na Graça, vislumbrou num 'bozó' as iniciais $T$. V., que coincidem com as de conhecido desportista."12
\end{abstract}

Dois anos antes, o jornal $A$ Tarde também havia noticiado:

"Foi outro dia, bem defronte do Tesouro do Estado, pela manhã. Local frequentadíssimo aquele. $O$ 'camarada' porém não estava ligando. Largou 0 'despacho', que ficou exposto à curiosidade dos que passavam. Uma galinha preta, três moedas de cobre, farófia amarela, uma boneca de pano espetada de alfinetes, uma camisa de homem, acaçás e outras bugigangas."13.

Manifestações de protesto da imprensa à parte, o fato é que essas duas fontes dão conta de que, apesar das restrições e mesmo dos riscos implícitos de se fazer um ebó com objetivos pouco louváveis, sua prática era corriqueira.

Esse é um aspecto da religiosidade afro-brasileira que confere oportunidade para manipulações inescrupulosas, pois dentro desse sistema religioso, um ebó que desequilibra 0 axé de uma pessoa gera a necessidade de ações protetoras e de reequilibrio. Essas ações se dão por meio de despachos para limpeza de corpo - quando o carrego é neutralizado. Uma vez

${ }^{12}$ A TARDE, 1937 (grifos do autor).

13 Idem, 1935 (grifos do autor). 
de "corpo limpo" a pessoa pode dar início a outros rituais que têm por finalidade recompor o axé desequilíbrado. Esses rituais podem limitar-se à simples limpeza de corpo ou estender-se a todos os rituais que compõem o processo de iniciação de um novo adepto.

Segundo a visão, um tanto parcial, de Edison Carneiro, os principais responsáveis pela abundância de ebós, em Salvador, eram os pais e mães de santo que jamais passaram pelo processo de iniciação, "sem treino, espontâneas, distantes da orgânica tradição africana"14. Ao dizer isso, Carneiro revela toda a sua restrição à tradição dos candomblés de caboclo e faz sua opção pela tradição jêje e nagô, às quais considerava mais próximas da matriz africana. Porém, também dentro da cultura popular há referências a comportamentos reprováveis de certos pais e mães de santo, que dão conta das exorbitâncias cobradas por esses sacerdotes.

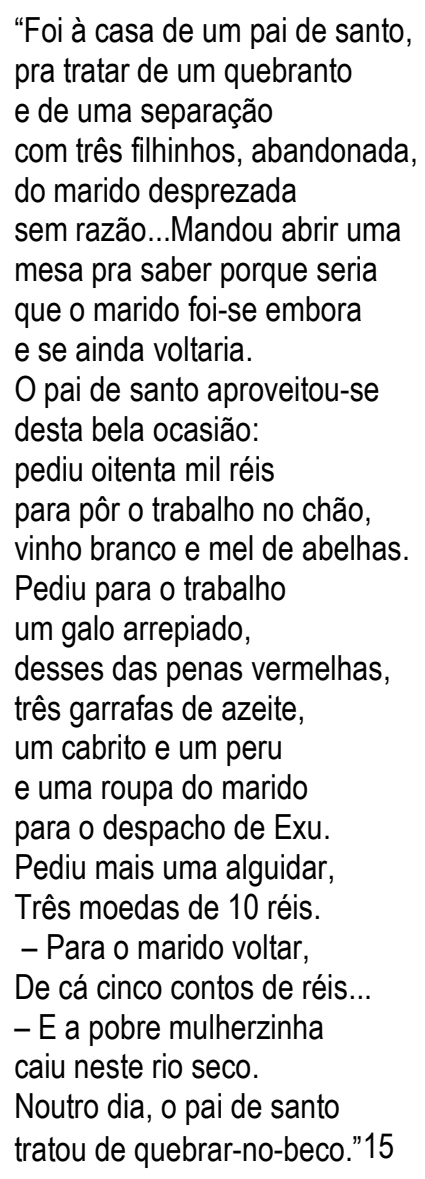

Além de fazer uma crônica sobre os logros que pessoas de boa fé poderiam sofrer ao confiar em espertalhões, esses versos populares ainda propiciam uma visão dos valores diferenciados entre os diversos tipos de serviços mágico-religiosos. Exemplificando, o pai de santo pediu $80 \$ 000$ para executar os rituais que envolviam a oferenda.

14 CARNEIRO, 2002, p. 106.

15 Ibidem, p. 107. 
Ao recordar as consultas com Martiniano do Bonfim e mãe Sabina, relatadas por Landes, percebemos que os $80 \$ 000$ dos versos revelam um acréscimo de $15 \$ 000$, em relação aos valores cobrados por Martiniano e por mãe Sabina para a execução de despacho. A diferença é que os $65 \$ 000$ pedidos pelo babalaô e pela mãe de santo envolviam todos os itens da oferenda e também o pro labore que eles receberiam para executar o ritual. No caso dos versos, o valor mencionado referia-se apenas ao pro labore para a execução do ritual de oferenda.

Oitenta mil réis representam aproximadamente 25 dias de trabalho de um operário da indústria têxtil, de acordo com os dados do recenseamento de 1920, cujo salário diário era de $3 \$ 174$. Já os sessenta e cinco mil réis representavam, aproximadamente, 20 dias de trabalho desse mesmo operário. Como os versos se referem a uma mulher com filhos para criar, que foi abandonada pelo marido, caso ela fosse operária da indústria têxtil, só o valor cobrado para "pôr o despacho no chão" representava 29 dias do seu trabalho. Já os sessenta e cinco mil réis, que foram pedidos por mãe Sabina e Martiniano do Bonfim, 23,7 dias de seu trabalho.

Quanto aos 5:000\$000 referentes ao ebó para fazer o marido da infeliz mulher voltar, considerando-se o salário diário, de $2 \$ 733$, das operárias da industria têxtil na Bahia, elas precisariam trabalhar cerca de 1.830 dias para obter essa quantia. Levando-se em conta o preço dos itens que comporiam o despacho e o ebó, assim como as quantias mencionadas nos versos populares, os valores serão significantes. 0 preço individual dos itens pode ser discriminado da seguinte forma:

QUADRO 1 - Preço unitário dos itens que compõem o despacho

\begin{tabular}{|c|c|}
\hline Item & Valor \\
\hline Vinho & $1 \$ 000$ \\
\hline Mel & $3 \$ 000$ \\
\hline Galo & $1 \$ 700$ \\
\hline Azeite & $10 \$ 000$ \\
\hline Cabrito & $50 \$ 000$ \\
\hline Peru & ----------- \\
\hline Alguidar & $\begin{array}{r}2 \$ 500 \\
68 \$ 200\end{array}$ \\
\hline
\end{tabular}


Para comprar apenas os ingredientes do despacho e do ebó, a "pobre mulherzinha" teria que dispor de aproximadamente $90 \$ 000$. Se considerarmos que só em três garrafas de azeite de dendê a mulher gastaria $30 \$ 000$, ou seja, o equivalente a 11 dias de seu trabalho, a soma de seus gastos alçaria nada menos que $88 \$ 200$, que acrescidos das três moedas de $\$ 10$ perfariam um total de $88 \$ 230$. Se, ao gosto baiano, adicionarmos uma "quebra", arredondando o valor para noventa mil réis, compensando o preço do peru que não pode ser apurado por falta de fontes, isso representaria, para uma operária da indústria têxtil, 33 dias de trabalho.

A partir dos dados do QUADRO 1, é possível fazer inúmeras digressões ou estabelecer comparações entre os valores de cada um dos itens ali relacionados, com os ganhos salariais de diversos ramos de atividades profissionais. Porém, temendo que, ao fazê-lo, o texto possa tornar-se demasiadamente longo e cansativo, creio ser melhor ater-me aos valores totais. Então, somando todos os valores mencionados nos versos e adicionando o valor dos itens para 0 despacho e para o ebó, a quantia total seria de 5:170\$030, que representa aproximadamente 1.892 dias de trabalho de uma operária da indústria têxtil. Dito isso, é de se supor que a "pobre mulherzinha" não era tão pobre.

Diante disso, creio caber a pergunta: Será que esses valores não estão um pouco distorcidos ou exagerados? Respondendo essa questão, Edson Carneiro afirmou:

\footnotetext{
"A acreditar na velha Izabel, que costumava botar mesa na casa de Justina, na Quinta das Beatas, era regra, há mais de meio século, pagar-se apenas 370 réis, sobre os quais se dormia, na véspera. Os tempos mudaram, a vida encareceu. $E$ já é comum que se fale de trabalhos de contos de réis. A mãe ou o pai cobra apenas cinco cruzeiros por consulta ao Ifá, mas o remédio indicado para caso particular sempre se eleva a alguns milhares de cruzeiros, que em geral chegam às suas mãos desta ou daquela maneira, para que a dificuldade seja removida."16
}

Tal afirmação implica informar que o valor cobrado por uma consulta, em finais do século $X I X$, era de $\$ 370$, que equivaleria a mais ou menos $1 / 5$ de $2 \$ 000$, isto é, do salário diário de um pedreiro ou carpinteiro em 189017. Em menos de meio século, houve um reajuste considerável no valor cobrado por uma consulta aos orixás. Se levarmos em conta que, em 1919, o valor pedido por tal serviço era de $5 \$ 000$ e representava, aproximadamente, dois dias de trabalho de um operário da "indústria de edificação", em 1920. Chegamos à conclusão que, em menos de cinquenta anos, o valor cobrado por uma consulta ao Ifá se elevou em $1.351 \%$.

\footnotetext{
${ }^{16}$ CARNEIRO, 2002, p. 122 (grifo do autor).

17 Cheguei ao final do século XIX e, consequentemente, à década de 1890 subtraindo cinquenta anos do ano de publicação da primeira edição do livro, da qual foi retirada a citação que faz referência ao valor da consulta ao Ifá. Para os valores dos salários, ver os GRÁFICOS 1 e 2.
} 
A pista para a compreensão dessa variação tão grande do valor cobrado pela consulta ao Ifá está na própria escrita de Carneiro, quando menciona, em seu texto, dois padrões monetários brasileiros adotados em distintos períodos. 0 real/ réis, padrão monetário do valor da consulta cobrada pela velha Izabel, que ele considerava uma soma bastante vultosa para a realização de um trabalho, vigorou no Brasil do período colonial até 1942. Em seguida, registrou que o valor cobrado por uma consulta ao Ifá, provavelmente na época em que fez o trabalho de campo e escreveu seu livro, era de Cr\$5,00. O cruzeiro, o novo padrão, vigiu no país de 1942 a 1967, e representou uma tentativa de reajuste econômico. Assim, os Cr\$ 5,00 (cinco cruzeiros) eram a conversão dos $5 \$ 000$ (cinco mil réis) ao novo padrão monetário.

Apesar de a "vida ter encarecido" com a inflação e as crises econômicas, não se elimina o fato de ter havido um aumento da procura desse tipo de serviço. Um dos prováveis elementos tensionadores para a elevação dos preços cobrados pelos despachos e ebós pode ter sido 0 grande afluxo de pessoas provenientes de setores sociais mais abastados e influentes.

A presença de políticos, empresários, pessoas da alta sociedade e, mesmo, a presença de pesquisadores estrangeiros nos terreiros de candomblé podem ter contribuído para uma elevação substancial dos preços cobrados para a prestação de serviços mágico-religiosos. É ainda Edison Carneiro quem informa o valor oferecido para se providenciar a morte de Ruy Barbosa, através de um ebó, e do preço pago pela mãe de santo que aceitou a encomenda.

\footnotetext{
"Conta-se que políticos da Bahia incumbiram Silvana de fazer um trabalho para eliminar Ruy Barbosa, dando-lhe doze contos. Silvana ter-se-ia dirigido ao seu orixá, explicando-lhe que, tendo empenhado a palavra não poderia recuar, ao que 0 encantado respondeu com o anúncio de sua própria morte, em seguida à do conselheiro. Mulher de palavra teria cumprido o prometido: 'Matou Ruy Barbosa, mas viajou também'."18
}

Observe-se o quão caro pagou pela encomenda da morte de um político. Esse pode ser um caso extremo, entretanto, não o único.

Na relação com Exu, a oferta de um ebó significa um pedido de sua intermediação em relação a algum problema ou uma forma de procurar agradá-lo para que deixe os caminhos abertos para a consecução de algum pedido ou ritual. Uma vez ele tendo aquiescido ao que the foi solicitado, está garantido o meio de circulação do fluxo de energias que irá favorecer os demais passos, rituais ou mesmo as ações daquele que ofertou o ebó.

\footnotetext{
${ }^{18}$ CARNEIRO, 2002, p. 127 (grifos do autor).
} 
Um adepto não irá recorrer apenas a Exu, negligenciando o seu próprio orixá. Eis porque, depois do ebó, seguem-se as oferendas aos orixás que viabilizarão 0 desfecho satisfatório às demandas que envolvem um pedido ou ritual a ser realizado.

As oferendas constituem-se, sobretudo, das comidas-rituais de cada orixá, sendo o seu preparo e oferecimento regidos por um conjunto de regras que devem ser rigidamente seguidas, sob pena de ofender o orixá e indispô-lo contra quem o negligenciou ou o desrespeitou. As oferendas - feitas, habitualmente, como forma de agradecimento ao orixá - assim como o ebó, têm seus custos definidos pela ocasião, pelo objetivo e pela disponibilidade de recursos para sua execução. Muitas vezes, os custos são elevados, pois, além da oferenda em si, há uma festa para comemorar a ocasião. Em outros momentos a oferenda é feita de modo mais privado.

Durante a oferenda deve-se cantar e saudar o orixá e, depois disso feito, deposita-se respeitosamente a comida-ritual em um determinado lugar, que pode ser no próprio quarto do santo, na mata, às margens de um rio ou em uma praia. Em alguns casos, as oferendas devem ficar pelo menos três dias aos pés do orixá, até que ela adquira um cheiro característico, antes de ser levada para algum desses lugares.

Segue uma lista preparada por mãe Anninha para o II Congresso Afro-brasileiro, onde figuram algumas comidas rituais dos orixás:

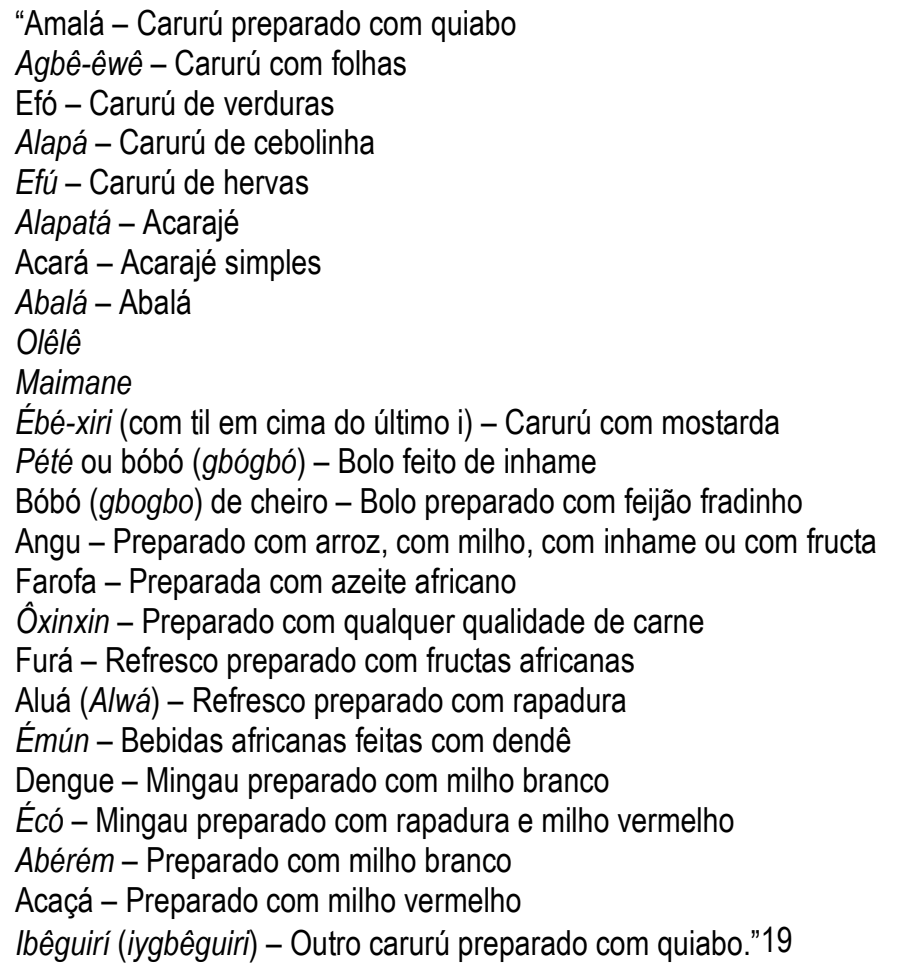

19 |I CONGRESSO... 1940, p. 357. 
Dentre as oferendas aos orixás, aquela que ganhou maior notabilidade de difusão foi 0 "caruru para Ibejis" - os santos católicos Cosme e Damião -, de acordo com o sincretismo religioso. É comum na Bahia oferecer-se carurus para "os meninos" como forma de agradecer a proteção concedida às crianças ou aos seus devotos e, ao fazê-lo, renovam-se os laços de proteção. A oferenda para os Ibejis, para quem tem esse compromisso, deverá ser realizada todos os anos. Ela, no entanto, pode dar-se de modos variados. Pode ser um caruru para 7, 14 ou 21 meninos ou, simplesmente, a oferta de dois pratinhos de caruru colocados em um lugar de mato verde, como forma de agradar "os meninos". Associa-se o grau de alegria e satisfação desses orixás à algazarra e bagunça feita durante a festa, o que faz com que os adeptos se esforcem para que ela ocorra dentro do conformes.

Despacho, ebó e oferendas representam apenas uma parte da liturgia do culto aos orixás. Eles necessariamente não marcam uma vinculação orgânica ou um compromisso mais sério de quem os oferece para com os orixás ou casas de culto. Essa vinculação só se concretiza com a iniciação do indivíduo. Através desse processo é que mais se percebe a concentração de esforço individual para levantar fundos, essências, para adesão à comunidade de filhos de santo de uma casa de culto.

É analisando a lista dos itens necessários à iniciação, em 1937, que se chega, finalmente, a uma relação muito próxima dos produtos que eram importados da Costa Ocidental da África para a Bahia. As listas foram levantadas por Herskovits (1958, p. 257) e estão organizadas da seguinte forma:

\section{Sacrifícios e acompanhamentos alimentícios}

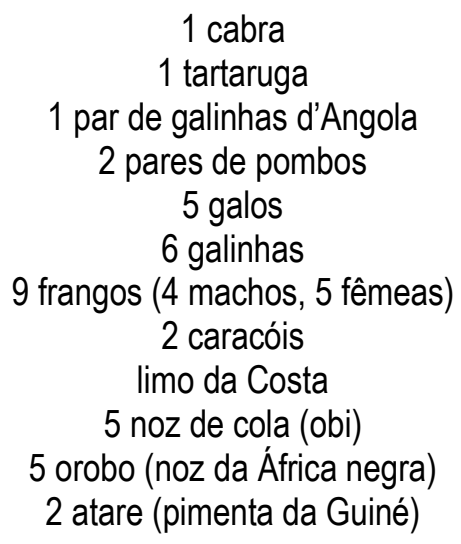

1 cabra

1 tartaruga

1 par de galinhas d'Angola

2 pares de pombos

5 galos

6 galinhas

9 frangos (4 machos, 5 fêmeas)

2 caracóis

limo da Costa

5 noz de cola (obi)

5 orobo (noz da África negra)

2 atare (pimenta da Guiné)

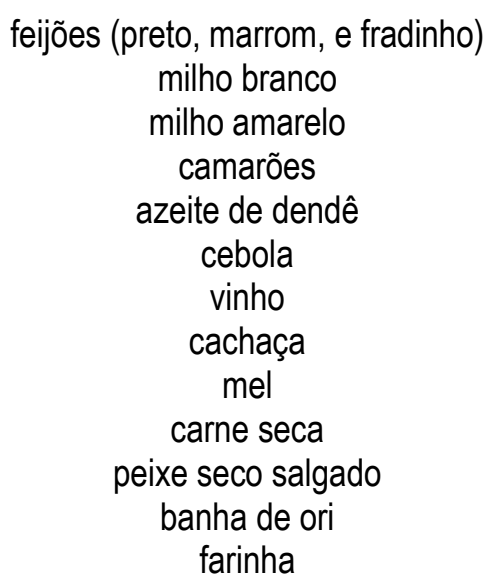

\section{Utensílios}

1 moringa de água grande

1 tamborete 


\author{
2 quartinhas \\ 1 moringa média de água \\ 3 pratos pequenos de porcelana \\ 1 prato grande de porcelana \\ 1 sopeiro de porcelana com tampa \\ 6 travessas (gamelas) \\ 1 par de tesouras \\ 1 navalha \\ 1 faca \\ 1 bacia grande \\ 2 cumbucas pequenas \\ 1 penico \\ Sabão da Costa \\ 1 lamparina
}

\author{
2 panela de barro \\ 2 panela esmaltada \\ 2 frigideira \\ 4 abanadores \\ 2 vassouras \\ 1 bule de café \\ 1 fogareiro \\ 4 colheres de madeira \\ 1 ralador \\ 1 pedra de moer \\ 3 bolas de giz branco \\ 2 bolas de giz amarelo \\ 3 bolas de giz multicolorido \\ 2 bolas de giz azul \\ 1 baú para a roupa da deidade
}

Comparando os itens constantes nas listas com as relações de produtos importados da Costa d'África, perceberemos inúmeros pontos de interseção. Em 1888, Esperança Felisberta trouxe de Lagos um carregamento contendo: panos da Costa, cuias, noz-de-cola e sabão da Costa. Samuel Luiz de França trouxe, além dos panos e das nozes-de-cola, limo da Costa, cuias e búzios. Uma década antes, um tal Eliseu do Bonfim, que talvez fosse o babalaô Martiniano Eliseu do Bonfim, trouxe, de Lagos, noz-de-cola, cuias e gaiolas de pássaros. As interseções não terminam aí, mas, no rol de produtos importados da Costa, constam ainda pedras de cal (giz), baús de couro, cuias, bebidas alcoólicas (vinho e genebra), azeite de dendê, aves etc. Por outro lado, há produtos que não constam dessa lista de itens para "feitura do santo", mas que, de um modo ou de outro, estão envolvidos no processo, tais como as diversas qualidades de pano da Costa, para se fazer as indumentárias dos orixás, e os búzios e palha da Costa, para compor as insígnias e confecção das roupas de algumas divindades.

O preço dessas mercadorias não era baixo. Um obi poderia custar o equivalente a sete dias de trabalho de um pedreiro, em 1850, cujo salário diário era de $1 \$ 200$. A aquisição de um animal para ser sacrificado exigia um esforço ainda maior do adepto que deveria comprometer a renda de seu trabalho, em muitos meses, ou até anos, para poder cultuar adequadamente o seu orixá. Vejamos, no QUADRO 2, o quanto representavam alguns itens da lista elaborada por Herskovits em relação à proporção de tempo de trabalho e valor monetário que um trabalhador, cuja média salarial diária era de $6 \$ 000$, por uma jornada de 12 horas de trabalho.

QUADRO 2 - Demonstrativo dos itens usados em um ritual de iniciação em relação à proporção de tempo trabalho, valor monetário e horas trabalho

$\begin{array}{cccccc}\text { Quant. } & \text { Itens } & \text { Valor unitário } & \text { Tempo de trabalho } & \text { Valor total } & \text { Dias de trabalho } \\ 01 & \text { Cabra } & 50 \$ 000 & 08 \text { dias e } 04 \mathrm{H} & 50 \$ 000 & 08 \text { dias e } 4 \mathrm{H} \\ 02 & \text { Galinha d'Angola } & 3 \$ 500 & 06 \mathrm{H}: 07 \text { min e } 30 \mathrm{seg} . & 7 \$ 000 & 01 \text { dia e 02 H }\end{array}$




$\begin{array}{cccccc}04 & \text { Pombo } & 2 \$ 500 & 5 \mathrm{H} & 10 \$ 000 & 01 \text { dia e } 08 \mathrm{H} \\ 06 & \text { Galinha } & 1 \$ 666 & 3 \mathrm{H}: 07 \text { min e } 30 \text { seg. } & 10 \$ 000 & 01 \text { dia e } 08 \mathrm{H} \\ 05 & \text { Obi } & 7 \$ 000 & 1 \text { dia e } 02 \mathrm{H} & 35 \$ 000 & 05 \text { dias e } 10 \mathrm{H} \\ 05 & \text { Orobô } & 7 \$ 000 & 1 \text { dia e } 02 \mathrm{H} & 35 \$ 000 & 05 \text { dias e } 10 \mathrm{H} \\ 10 \mathrm{I} & \text { Azeite de dendê } & 1 \$ 000 & 02 \mathrm{H} & 10 \$ 000 & 01 \text { dia e } 08 \mathrm{H} \\ 05 \mathrm{~kg} & \text { Feijão fradinho } & 1 \$ 000 & 02 \mathrm{H} & 5 \$ 000 & 10 \mathrm{H} \\ 01 \mathrm{~kg} & \text { Feijão preto } & 1 \$ 000 & 02 \mathrm{H} & 1 \$ 000 & 02 \mathrm{H} \\ 02 \mathrm{~kg} & \text { Milho branco } & 1 \$ 000 & 02 \mathrm{H} & 2 \$ 000 & 04 \mathrm{H} \\ 03 \mathrm{~kg} & \text { Milho amarelo } & \$ 400 & 48 \mathrm{~min} . & 1 \$ 200 & 02 \mathrm{H} \mathrm{e} 24 \mathrm{~min} . \\ 02 \mathrm{I} & \text { Vinho } & 1 \$ 000 & 02 \mathrm{H} & 2 \$ 000 & 02 \mathrm{H} \\ 02 \mathrm{I} & \text { Cachaça } & 1 \$ 000 & 02 \mathrm{H} & 2 \$ 000 & 02 \mathrm{H} \\ 01 \mathrm{I} & \text { Mel } & 3 \$ 000 & 06 \mathrm{H} & 3 \$ 000 & 06 \mathrm{H} \\ 01 & \text { Pimenta da Costa } & 4 \$ 000 & 08 \mathrm{H} & 4 \$ 000 & 08 \mathrm{H} \\ 6 \mathrm{I} & \text { Camarão } & 2 \$ 000 & 02 \mathrm{H} & 12 \$ 000 & 2 \text { dias } \\ 04 & \text { Abanadores } & 2 \$ 500 & 05 \mathrm{H} & 10 \$ 000 & 1 \text { dia e } 08 \mathrm{H} \\ \text { Totais } & 89 \$ 566 & & 179 \$ 200 & & \end{array}$

A lista apresentada no QUADRO 2 representa apenas uma parcela dos itens necessários para uma iniciação no culto aos orixás. Esses 17 itens significavam, para um trabalhador, aproximadamente 30 dias de trabalho. Nessa lista, não consta, por exemplo, o custo da confecção das roupas rituais. A sua inclusão elevaria esse valor a números mais relevantes.

Considerando que as estatísticas do censo de 1920 apresentam algumas categorias com uma remuneração muito baixa, é preciso lembrar que, sendo Salvador uma cidade onde a prática do comércio sempre funcionou como uma forma de complementação da renda pode-se supor uma elevação, ainda que modesta, da renda média do trabalhador soteropolitano. A prática de trabalhos alternativos, mais ou menos frequentes, os chamados "biscates", ajudava a equilibrar as despesas domésticas dos trabalhadores, de modo geral.

Para os adeptos do culto aos orixás, além das despesas com sua própria manutenção, havia ainda o custo adicional relacionado ao culto dos orixás. Dessa forma, além dos trabalhos complementares, era necessário recorrer, sempre que preciso, às redes de solidariedade, nas quais os membros das comunidades de santos se abrigavam das vicissitudes. Essas redes possibilitavam a aquisição de crédito ou dos recursos necessários para a compra dos objetos destinados ao culto dos orixás, como descrito anteriormente, ao se tratar de prática de prestações totais dentro das casas de culto. Sem essas estratégias, a prática religiosa, nos modos como ela se processou, seria muito mais difícil.

Se observarmos a QUADRO 2 e compararmos os itens ali constantes, em termos de preço, perceberemos que aqueles originários da Costa d'África possuíam um valor muito mais elevado que os demais. É o caso, por exemplo, da pimenta da Costa (Ataré), cuja unidade representa para um trabalhador, com uma média salarial diária de $6 \$ 000$ nada menos que oito horas de trabalho. Para alguém que possuísse um salário diário de $2 \$ 000$, esse mesmo produto 
representaria dois dias de trabalho. Isso colocaria itens como uma cabra ou mesmo os 5 obi e 5 orobôs muito além de seu poder aquisitivo.

Isso faz pensar na motivação e na quantidade de trabalho empregado por essas pessoas, de origem modesta, para realizar as cerimônias e as obrigações para com seus orixás, e conclui que, de fato, eles deveriam zelar pelos seus fiéis, conferindo-lhes a energia necessária para sobreviver, reproduzir-se e manter acesas suas tradições religiosas.

Há questões, porém, que precisam ser analisadas: Por que importar produtos do continente africano, havendo produtos equivalentes no Brasil? Será que esse fluxo se manteve com 0 intuito de preservar a pureza das "tradições africanas" que já sofriam significativa influência de outras experiências religiosas? Para além das possíveis querelas entre os candomblés de caboclo e os de nação - ketu, jeje e nagô -, principalmente esse último, o que quero considerar são as dimensões (simbólica, religiosa e social) da perpetuação do fluxo comercial constante com o continente africano para as casas de culto, fossem elas de caboclo, jeje, ketu ou nagô.

A importação de produtos da Costa d'África, na sua origem, de fato se deu por motivações identitárias, conforme assinalado neste texto. A manutenção desses vínculos respondeu a uma agenda política dos terreiros vinculados à cultura yorubá. A aura mística e 0 fetiche criados em torno dos produtos vindos da "Costa" foram tão eficientes que repercutiram também nos candomblés de caboclo.

Uma das principais críticas feitas pelos líderes da "ortodoxia nagô" aos candomblés de caboclo era o fato de que muitos deles não haviam passado por um processo ritual de iniciação nos moldes nagôs.

\footnotetext{
"Provavelmente que o pouco tempo transcorrido entre a consagração ao Orixá e a elevação do iniciado a Pai de Santo, portanto, zelador dos fundamentos e do Axé da casa, esteja a principal fonte de desentendimento entre os adeptos do Candomblé de Caboclo e os adeptos do Culto aos Orixás, uma vez que subvertia a noção de ancestralidade direta, isto é, de hereditariedade, bem como, a noção de hierarquia a partir do tempo de "feitura" do Orixá, pré-requisito necessário para que 0 adepto seja iniciado em todos os preceitos da religião. Esse posicionamento dos Candomblés de Caboclos facilitava a multiplicação das casas de santos, por um lado contribuindo para o aumento do número de adeptos, comprometendo, por outro, como aliás protestavam os líderes nagôs, a profundidade dos ritos, as práticas religiosas e a ética da religião."20
}

Isso não significava que esses líderes dos candomblés de caboclo dispensassem os novos adeptos dos rituais de iniciação, assim como o uso, nesses rituais, dos artigos vindos da

20 SANTOS, F. G., 2001, p. 88. 
"Costa". Embora a iniciação nos candomblés de caboclo fosse menos demorada e rigorosa para os padrões ketu, jeje e nagô, ainda assim, ela existia. O rol de gêneros utilizados na "feitura do santo", apesar de certos incrementos, mantinha os seus aspectos primordiais. A diferença estava na ritualização e não no que era utilizado, exemplificando, não se dispensava o "obi".

A variação acentuada estava, não na substituição, mas na agregação de novos elementos, novos rituais e, principalmente, a aceitação no seu panteão de novas divindades, os caboclos, a que os líderes da ortodoxia nagô chamavam de "mistura". Creio que a adjetivação do candomblé como sendo de caboclo, ao menos nos primeiros momentos, tenha ocorrido de fora para dentro, contribuindo significativamente, para isso, a atuação de etnólogos como Edson Carneiro, Ruth Landes, Donald Pierson e outros. O próprio Peirson relatou:

"O empréstimo ritual de seita para seita acontece algumas vezes mesmo no caso dos centros mais ortodoxos gêge-nagôs e congo-angola. E, além disso, essas seitas não escaparam inteiramente à influência indígena."21

Assim, os elementos primordiais que motivaram e justificaram a utilização dos produtos originários do continente africano, característicos dos candomblés de vertente yorubá, não desapareceram nos candomblés de caboclo, haja vista a crença de que esses produtos contêm e conferem mais axé que os congêneres nacionais e condedem maior prestígio social aos adeptos que os utilizam em suas obrigações e preceitos.

Em relação à eficácia dos produtos originários da Costa d'África e suas propriedades especiais em relação ao axé foram referidos em outras partes deste texto. É preciso considerar que a organização hierárquica do candomblé é dada, sobretudo, pela noção de senhoridade, está suscetível à noção de prestígio social. Um terreiro de candomblé em muito se assemelha a uma corte real, onde existem regras de cortesia, reverências e uma série de distintivos, rituais e sociais, que identificam o lugar do indivíduo dentro do grupo, naquela comunidade.

Desse modo, tal qual em qualquer corte, o luxo e a ostentação conferem prestígio social aos que deles se valem. $O$ fausto e a ostentação de um abiã podem ser avaliados no seu zelo quando escolhe os itens que comporão seu enxoval de iniciação. Nesse caso, a utilização de produtos vindos da Costa d'África conferia certo prestígio dentro da comunidade de santo, que sempre estava atenta e disposta a fazer as devidas censuras éticas, morais e ritualísticas de forma velada ou explícita. Nesse caso, esse iniciado poderia adquirir, inclusive, dentro da hierarquia de seu barco de iaô uma posição de destaque, já que os produtos da Costa d'África

\footnotetext{
21 PIERSON, 1971, p. 9-10.
} 
agregam mais axé que os de outra procedência. Ele pode, por exemplo, ser escolhido como dofono daquele barco.

O dofono é aquele que, dentro de um barco de iaô, foi iniciado primeiro. Embora as prescrições ritualísticas que definem a hierarquia em um barco de iaô informem que os filhos de Ogum e de Oxalá têm precedência sobre os demais na ordem de iniciação, Vivaldo da Costa Lima informa que:

\footnotetext{
"[...] os mecanismos de ajustamento situacionais dos candomblés permitem, às vezes, que preferências pessoais das mães-de-santo ou suas simpatias por determinado orixá alterem essas normas para dar a uma abiã promissora ou preferida, ou ao filho de um orixá especialmente querido, a preeminência no grupo de iniciação com o status de dofono."22
}

Nesse sentido, é possível pensar que a crença em um axé maior dos produtos vindos da Costa d'África confere maior eficácia à realização dos rituais, inclusive o de iniciação, e prestígio social dentro da comunidade de santo. Então teríamos dois componentes simbólicos e ideológicos que também explicariam o porquê de os adeptos dos candomblés de caboclo se sentirem seduzidos por privilegiar a sua utilização. Ainda mais porque é a partir do prestígio social de um adepto que as portas para os conhecimentos rituais são abertas, possibilitando, a ele, a aquisição tanto do conhecimento ritual, quanto da senhoridade que lhe permitirá galgar a difícil hierarquia de uma casa de culto aos orixás.

\section{Considerações Finais}

É possível concluir que, para os adeptos do candomblé, a riqueza é desejada, portanto, é um fim, vez que ela é um meio pelo qual se pode melhor cultuar os orixás.

Partindo desse pressuposto, a relação dos adeptos do candomblé e dos seus representantes religiosos será completamente distinta de outras formas de manifestação religiosa. Não há porque ter vergonha de ter, pedir ou falar de dinheiro. 0 dinheiro traz axé para quem dá e para quem recebe. E considerando que uma das pedras fundamentais do culto aos orixás é que 0 adepto deve manter o seu próprio axé em equilíbrio, para que possa gozar de proteção, saúde e fortuna, o dinheiro deve ser entendido como um meio e um fim para isso.

A desobediência ou o não cumprimento de alguma obrigação ou oferenda devida ao orixá, segundo a doutrina, pode incorrer em danos, por vezes fatais, ao fiel que não cumpre a sua parte no sistema de dons e contradons estabelecido entre ele e os orixás. Esse é o princípio que rege, de modo geral, as manifestações religiosas do candomblé de onde brota o mercado

\footnotetext{
22 LIMA, 2003, p. 72.
} 
consumidor dos objetos de culto aos orixás. Embora as mercadorias não sejam baratas, e nunca tenham sido, o adepto sempre encontrou e encontrará as motivações ou os elementos persuasivos para consumir os produtos relacionados ao seu orixá.

Sendo um comércio para iniciados, tanto no que se refere à venda quanto à compra, a posse de um conhecimento litúrgico e das propriedades e características da mercadoria comprada é a principal salvaguarda contra as possíveis adulterações e falsificações dos produtos.

Além da necessidade de cultuar 0 orixá, há outras circunstâncias que implicam a necessidade do adepto, ou mesmo do simples frequentador, abastecer com as mercadorias relacionadas à liturgia do candomblé. Algumas dessas circunstâncias estão associadas a tratamento de moléstias físicas e espirituais, a rituais que conferem proteção pessoal ou mesmo a fins menos nobres e bondosos. 0 fato é que o culto e a manifestação de respeito, de agradecimento ou qualquer outro tipo de reverência religiosa no candomblé implicam um custo que, necessariamente, representa uma operação de compra e venda ou de pagamento por alguma prestação de serviço.

Apesar de se tratar de uma relação comercial intimamente ligada à dinâmica religiosa, nem por isso deixa de ser comércio, com todas as características e nuanças de qualquer ramo de atividade que envolva a compra e a venda de uma mercadoria. Seus objetivos e finalidades gravitam também em torno do lucro, do mercado consumidor, da lei da oferta e procura. Nesse sentido, seu caráter mundano e material interfere na ritualização religiosa.

\section{Referências Bibliográficas}

BATISTA, José Renato de Carvalho. "'No candomblé nada é de graça...': estudo preliminar sobre a ambiguidade nas trocas no contexto religioso do Candomblé". Revista de Estudos da Religião, São Paulo, ano 5, n. 1, pp. 68-94, 2005. Trimestral.

CARNEIRO, Edison. "O médico dos pobres". In: VV.AA. O negro no Brasil: trabalhos apresentados no II Congresso Afro-brasileiro (Bahia). Rio de Janeiro. Civilização Brasileira, 1940.

HERSKOVITS, Melville J. "Some economic aspects of the Afrobahian Candomble". In: Miscelânea Palu Rivet Octogenariio Didacta. México, DF: Universidad Autonoma de Mexico, 1958. Studies).

The new world Negro. Bloomington: Minerva Press, 1966. (Selected Papers in Afroamerican

LIMA, Vivaldo da Costa. A família de santo nos candomblés jeje-nagôs da Bahia. Salvador: [s.n.], 1977.

PIERSON, Donald. Brancos e pretos na Bahia: estudo do contato social. São Paulo: Ed. Nacional, 1971.

SANTOS, Flávio Gonçalves dos. Os discursos afro-brasileiros face às ideologias raciais na Bahia/ 18891937. Dissertação de Mestrado em História, Universidade Federal da Bahia, Salvador, 2001. 
VERGER, Pierre. Fluxo e refluxo do tráfico de escravos entre o Golfo do Benin e a Baia de Todos os Santos, entre os séculos XVII e XIX. São Paulo: Currupio, 1987. Lendas africanas dos orixás. Salvador: Corrupio, 1981. Candomblés da Bahia. 9. ed. Rio de Janeiro: Civilização Brasileira, 2002. 